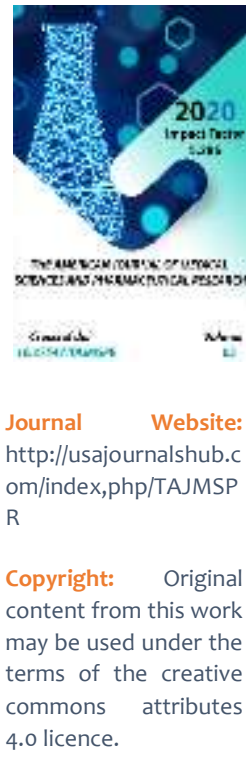

\title{
Prevention Of Various Diseases Encountered In Children
}

\author{
Arzikulova Munisa Shuxratovna \\ Samarkand State Medical Institute Assistant At The Department Of Pediatric Dentistry, \\ Uzbekistan
}

Shukurov Sherzod Shuxratovich

Samarkand State Medical Institute Assistant At The Department Of Pediatric Dentistry, Uzbekistan

Axrorova Malika Shavkatovna

Samarkand State Medical Institute Assistant At The Department Of Pediatric Dentistry, Uzbekistan

\section{ABSTRACT}

This article is mainly included in the information in the article about dental diseases and how to be without them. The article mainly contains information on dental diseases.

\section{KEYWORDS}

Herpes virus, infection, groprinosin, Oral infection, gingivostomatitis.

\section{INTRODUCTION}

Dental caries is a sufficiently serious problem that many people face. This process has many negative consequences. Therefore, you need to think about the Prevention of the disease, as well as timely treatment of it. There are also a lot of options on how to treat dental diseases at home. Each method has its own positive properties and characteristics.

Dental caries is a complex pathological process that occurs after tooth extraction. Hard tissues become soft, which leads to the appearance of cavities. Translated from Latin, this term literally means "decay", most often it is used in various diseases of the hard tissue of the teeth, where the signs are the decay of dentin and enamel.

Tooth caries disease manifests itself at different ages and in different forms. Often the problem begins due to the activity of bacteria, such as Streptococcus Mutants, which usually accumulate on the surface of the tooth enamel in the form of plaque. You can remove it with a toothbrush and a special solution for rinsing the oral cavity. Dentists distinguish two stages of caries: the first is characterized by the appearance of a white or pigmented spot; the 
second is when a defect in the hard tissues of the tooth is already felt.

\section{MATERIALS AND METHODS}

Despite the fact that many people perceive caries as a simple and incomprehensible situation that can be solved later, everything is different. The fact is that problems with teeth directly affect the quality of processing food in the oral cavity of a person, in turn, the functioning of his digestive system. Complications of caries lead to a multifunctional and aesthetic point of view. This includes:

A constant source of infection can cause an allergic reaction in a person.

The disease affects the work of the organs of the circulatory system.

The disease is common among those who have developed caries. Pulpit, periodontitis and oozing - this is not a complete list of problems.

If there are sick teeth, the load during chewing falls only on one side of the oral cavity, which leads to poor-quality chewing of food. This, in turn, leads to gastritis, ulcers and digestion.

Aesthetic discomfort is also important. Because of bad teeth, a person feels insecurity in society, a smile, a laugh, a twinge in communicating with people.

\section{DISCUSSION AND ACKNOWLEDGEMENT}

\section{Causes}

Herpetic stomatitis is an infection caused by the herpes simplex virus (HSV), or oral herpes. Young children commonly get it when they are first exposed to HSV. The first outbreak is usually the most severe. HSV can easily be spread from one child to another. If you or another adult in the family has a cold sore, it could have spread to your child and caused herpetic stomatitis. More likely, you won't know how your child became infected.

\section{Etiology}

The causative agent is Herpes simplex virus type 1 (HSV-1), which belongs to the alphaherpesvirus group. The virus is enveloped and has a linear double-stranded DNA genome. HSV-1 is mostly responsible for oral, ocular, and facial infections as it has a tropism for oral epithelium. While most cases of herpetic gingivostomatitis are associated with HSV-1 infection, some adult cases have been reported where HSV-2 was isolated from the oral lesions. Oral infection with HSV-2 is probably transmitted through urogenital contact and has also been observed in HIVpositive patients and patients undergoing immunosuppressive therapy.

\section{Epidemiology}

Primary herpetic gingivostomatitis typically occurs in children younger than the age of 5 years, but can also occur in adolescents and adults. HSV-1 is usually acquired in childhood by coming into contact with the oral secretions. It is estimated that almost $90 \%$ of the world's population is seropositive for HSV-1 by 35 years of age, and half of the individuals carrying the virus will experience reactivation in the form of herpes labial is. Herpetic gingivostomatitis is equally distributed amongst gender and race groups and is not found to have a particular seasonal or geographic distribution.

\section{Treatment}


Treating gingivostomatitis focuses on providing relief from the painful symptoms and getting rid of the infection.

Standard ways to reduce the discomfort associated with gingivostomatitis include:

taking over-the-counter pain relievers, as directed rinsing the mouth with a saltwater solution ( $1 / 2$ teaspoon of salt in 1 cup of warm water) using medicinal mouthwashes drinking plenty of water; eating soft, bland foods, such as applesauce, mashed bananas, and warm oatmeal, that make eating less painful.

A doctor may also prescribe acyclovir, which also helps treat chickenpox, herpes simplex, and shingles. Studies have found that the use of acyclovir:

shortened the duration of symptoms by $20-50$ percent led to more rapid healing of sores helped people return to regular eating and drinking habits faster.

Symptoms of gingivostomatitis usually disappear without medical treatment within 1 to 2 weeks, but the infection may recur. People also need to take steps to prevent the spread of gingivostomatitis, particularly among young children. The condition spreads through saliva and by touching the sores, so it is sensible to try to avoid close contact with infected people, and not to allow children with gingivostomatitis to share toys or personal items.

\section{CONCLUSION}

Those Groprinosin is prescribed to children from the 1st year of life at the rate of 50-100 mg / kg per 3-4 doses (after meals), on average 5-7 days. For preventive purposes, it is mean at a dose of $50 \mathrm{mg} / \mathrm{kg}$ per day 3 times in week for 3-9 weeks. For the prevention of acute herpes it is necessary to protect drive strict sanitary control with the use of individual masks hygiene products and dishes, cleanliness control stats of hands, a ban on kissing a child and samples of his food, regularly ventilated room installation, etc.

\section{REFERENCES}

1. Elizarova V. M., Drobotoko L. N., Strakhova S. Yu. / / Lech. doctor. - 2000. - no. 8. - P. 2729.

2. Isakov V. A., Rybalkin S. B., Romantsov M. $G$. herpesvirus infection: a manual for doctors. - SPb., 2006. - 95 p.

3. Levonchuk E. A. herpetic infection of a polostyrta // Tell lies. dentistry. - 2005. №1. - C.19-23

4. Looker, KJ; Garnett, GP; Schmid, GP (October 2008). "An estimate of the global prevalence and incidence of herpes simplex virus type 2 infection". Bulletin of the World Health Organization. 86 (10): 805-12, A.

5. Dickerson FB, Boronow JJ, Stallings $C$, et al. (March 2004). "Infection with herpes simplex virus type 1 is associated with cognitive deficits in bipolar disorder". Biol. Psychiatry. 55 (6): 588-93.

6. Rapini, Ronald P.; Bolognia, Jean L.; Jorizzo, Joseph L. (2007). Dermatology: 2Volume Set. St. Louis: Mosby. ISBN 978-14160-2999-1.

7. Baratova Sh.N., Rakhimberdiev R.A., Shamsiev R.A. "Features of the course and diagnosis of dental caries in primary school children." Achievements of science and education - scientific and methodological journal, 2020, No. 1 (55), pp. 83-88

8. Zubaidullaeva M.A., Rakhimberdiev R.A., Shamsiev R.A. "Hygienic care of the oral cavity in young children." Achievements of science and education - scientific and 
methodological journal, 2020, No. 1 (55), pp. 88-94

9. Baratova Sh.N., Rakhimberdiev R.A., Shamsiev R.A. "Prevention of caries of permanent teeth in children of primary school age." Achievements of science and education - scientific and methodological journal, 2020, No. 4 (58), pp. 67-75

10. Zubaidullaeva M.A., Rakhimberdiev R.A. "Dental caries in young children: epidemiology, etiology, prevention, treatment." Achievements of science and education - scientific and methodological journal, 2020, No. 4 (58), pp. 79-88

11. Indiaminova G.N., Zoirov T.E. "Optimization of the provision of dental care for mentally retarded children in special support schools" Journal of Natural Remedies, JNROnline Journal ISSN: 23203358 (e) ISSN: $0972-5547$ (p), Vol. 21, No. 6, (2020), 84-86 pages

12. Shukurov Sh. Sh., Arzykulova M. Sh., Axrorova M. Sh. "Transitional features of acute herpetic stomatitis in children and modern approaches to treatment" The american journal of medical sciences and pharmaceutical research. The USA Journals, USA ISSN 2689-1026, Volume 2 Issue 9, 2020, 15-18pages

13. Oblokulov A.T., Rakhimberdiev R.A. "Optimization of treatment of acute herpetic stomatitis in schoolchildren." Journal of Biomedicine and Practice, 2020, Special Issue-2, pp. 799-802

14. Indiaminova G.N. "Terms of orthodontic treatment in patients with dentoalveolar anomalies with and without extraction of individual teeth." Journal of Biomedicine and Practice, 2020, Special Issue-2, pp. 803806

15. Oblokulov A.T., Saidmurodova Zh.B. "Phytotherapy in the treatment of acute herpetic stomatitis in children." Re-health electronic scientific and practical journal, 2020, No. 2.2 (6), pp. 130-133
16. Oblokulov A.T., Saidmurodova Zh.B. "Evaluation of the effectiveness of therapeutic pads based on calcium hydroxide in the treatment of deep caries in children" Re-health electronic scientificpractical journal, 2020, No. 2.3, pp. 115-118

17. Shukukrov Sh.Sh., Arzikulova M.Sh., Sanakulov M.A. "Tish kattik tukimalari nocariasis casalliklarning tarkalishi va hamrokh casalliklar bilan boglikligini bakholash" Dentistry and craniofacial research electronic scientific and practical journal, 2020, No. 1. (1) pp52-55

18. LINGUISTICS AND LINGUISTIC DISCIPLINES, Ergasheva N.K. Senior teacher Department of foreign languages in natural sciences Faculty of foreign languages Ferghana State University Ferghana, Republic of Uzbekistan, "Economy and society" http://www.iupr.ru, 63-66 p 